\title{
Effect of Schizochytrium sp., on the Growth, Fatty Acid Composition, Digestive Enzyme and Serum Biochemical Composition of Postlarval Litopenaeus vannamei
}

\author{
Guofang Zhong 1, 2, 3, *, Jovin Hasjim ${ }^{4}$, Blandine Baert ${ }^{5}$, Ling Lu ${ }^{4}$ \\ ${ }^{1}$ National Demonstration Center for Experimental Fisheries Science Education, Shanghai Ocean University, Shanghai, China \\ ${ }^{2}$ Shanghai Engineering Research Center of Aquaculture, Shanghai Ocean University, Shanghai, China \\ ${ }^{3}$ Centre for Research on Environmental Ecology and Fish Nutrion (CREEFN) of the Ministry of Agriculture, Shanghai Ocean University, \\ Shanghai, China \\ ${ }^{4}$ Roquette Management (Shanghai) Co., Ltd., Shanghai, China \\ ${ }^{5}$ Roquette Lestrem, Paris, France
}

Email address:

gfzhong@shou.edu.cn (Guofang Zhong)

*Corresponding author

\section{To cite this article:}

Guofang Zhong, Jovin Hasjim, Blandine Baert, Ling Lu. Effect of Schizochytrium sp., on the Growth, Fatty Acid Composition, Digestive Enzyme and Serum Biochemical Composition of Postlarval Litopenaeus vannamei. Agriculture, Forestry and Fisheries.

Vol. 9, No. 1, 2020, pp. 14-21. doi: 10.11648/j.aff.20200901.12

Received: November 11, 2019; Accepted: November 28, 2019; Published: April 14, 2020

\begin{abstract}
In this study, shrimp feed was substituted with a dried alga, Schizochytrium sp., at five levels $(0,10,20,40$, and $60 \%$ of compound feed) to yield protein/energy (P/E) ratios of 22.72, 19.75, 16.71, 13.72 and $10.75 \mathrm{mg}$ protein/KJ, respectively. The effects of this substitution on the specific growth rate (SGR), survival rate, fatty acid composition, digestive enzyme activities and biochemical composition of the sera in postlarval white shrimp (Litopenaeus vannamei) were evaluated. Four replicates, each consisting of 5,000 postlarval shrimp in a single cage, were performed at each substitution level. The postlarval shrimp were randomly distributed to 20 cages, and the duration of the trial was $50 \mathrm{~d}$. The results showed that the best performance was obtained with a diet containing $40 \%$ dried Schizochytrium. The survival rate of the $40 \%$ trial group was $24 \%$ higher than that of the shrimp fed a control diet $(p<0.05)$. The final body weight gain and SGR peaked at a substitution level of $40 \%$ dried Schizochytrium $(p<0.05)$. The feed conversion ratios (FCRs) of the $20 \%$ and $40 \%$ trial groups were significantly lower than that of the control group $(p<0.05)$. The muscle protein and ash contents of the shrimp fed diets containing $20 \%$ and $40 \%$ dried algae were higher than those of the shrimp fed the control diet $(p<0.05)$. Although the level of dried Schizochytrium was associated with a decrease in the protease specific activity, an increase in the lipase activity was observed. The serum biochemical composition of the shrimp was significantly affected by the level of dried Schizochytrium in the diet $(p<0.05)$. In summary, when the feed content of dried Schizochytrium ranged from 20 to $40 \%$, an optimal P/E ratio of 13.72-16.71 mg protein/KJ was achieved. Thus, such supplementation could increase the amount of highly unsaturated fatty acids (HUFAs) and decrease the required level of protein in the production of high-quality feed.
\end{abstract}

Keywords: Schizochytrium sp, Fatty Acids, Growth, Proteases, Lipases, Serum Lipid and Protein Composition

\section{Introduction}

Litopenaeus vannamei was introduced to China in 1988 and rapidly became the most common shrimp species cultured in China. Larval shrimp breeding is still dependent on live prey, such as rotifers and Artemia, and during the transfer from live prey to formulated diets, high mortality and poor growth of larval shrimp have consistently been observed [1]. Thus, the substitution of appropriate formulated diets for live prey is crucial for sustaining the production of high-quality juvenile $L$. vannamei, and a cost-effective and nutritionally balanced feed formulation must be developed for this species in the future.

Marine fish meals and fish oils are often included in $L$. 
vannamei feed formulations because they provide excellent sources of high-quality essential amino acids, attractants, and highly unsaturated fatty acids (HUFAs). However, because of the unstable prices associated with fluctuations in the supply of these materials, the replacement of these marine ingredients with cost-effective alternative sources of proteins and lipids in aquaculture feeds is a high-priority task for feed mills and aquaculturists [2]. Numerous studies have evaluated the potential use of specific protein or lipid sources as alternatives to fish meals and fish oil in aquatic feeds [3-6]. However, these alternative sources usually lack HUFAs, especially docosahexaenoic acid (DHA), which is considered essential for the appropriate growth and survival of L. vannamei [7] because it cannot be synthesized de novo by this species. Therefore, DHA should be added to the feed [8]. In addition to fish oil and fish meal, another potential option that has been explored as a source of DHA in aquaculture feeds is the use of heterotrophic microalgae, such as Schizochytrium sp. [7, 8]. Patnaik et al. (2006) [7] found that DHA levels of $5 \mathrm{~g} \mathrm{~kg}^{-1}$ performed better than levels of $20 \mathrm{~g} \mathrm{~kg}^{-1}$ in L. vannamei diets. Samocha et al. (2010) [8] compared the performance of juvenile L. vannamei offered a HUFA-deficient diet with that of juveniles offered diets containing HUFA sources from Schizochytrium sp. fermentation products or marine ingredients and found that the Schizochytrium sp. fermentation products represented a viable dietary source of DHA as a replacement for marine fish oil. The use of a high-quality formulated diet is crucial for the growth performance and survival of $L$. vannamei from the postlarval to the juvenile stage, and the nutritional requirements of different stages of L. vannamei differ. However, previous research has not focused on the effects of including Schizochytrium sp. in the diet of late postlarval L. vannamei. Increasing the fat content of the diet would make it feasible to add less protein, and the use of an appropriate protein/energy $(\mathrm{P} / \mathrm{E})$ ratio is conducive to the growth performance of $L$. vannamei [9]. Hence, the objective of this study was to test the growth performance, digestive enzyme activity and serum biochemical composition of late postlarval L. vannamei fed diets containing various levels of Schizochytrium sp. fermentation products as the primary lipid and DHA source.

\section{Materials and Methods}

\subsection{Experimental Design}

Dried Schizochytrium sp. was used in the shrimp feed at five levels: 0 (control), 10, 20, 40, and $60 \%$ of the proximate composition of the experimental diets, and the $\mathrm{P} / \mathrm{E}$ ratios of the diets at these levels of supplementation were 22.72, 19.75, $16.71,13.72$ and $10.75 \mathrm{mg}$ protein/KJ, respectively. The percentage of fish meal in the individual diets was decreased to $13.33,26.66,40.00$, and $53.33 \%$ the level in the diet fed to the control group (Table 1). Each treatment included four replicates, and each replicate consisted of 5,000 postlarval shrimp placed in a single cage with a surface area of $4 \mathrm{~m}^{2}$ and a depth of $1.5 \mathrm{~m}$. The dried Schizochytrium $\mathrm{sp}$. was produced by Roquette (Wuhan, Hubei, China).

Table 1. Ingredients and proximate compositions of experimental diets (DM basis\%).

\begin{tabular}{|c|c|c|c|c|c|}
\hline & \multicolumn{5}{|l|}{ Diet } \\
\hline & $0 \%$ & $10 \%$ & $20 \%$ & $40 \%$ & $60 \%$ \\
\hline Fish meal & 30.00 & 26.00 & 22.00 & 18.00 & 14.00 \\
\hline Peanut meal & 10.00 & 6.38 & 0.24 & 1.00 & 0.00 \\
\hline Soybean meal & 24.00 & 19.00 & 17.00 & 6.00 & 1.00 \\
\hline Shrimp shell powder & 2.00 & 2.00 & 2.00 & 2.00 & 2.00 \\
\hline Beer yeast & 3.00 & 3.00 & 3.00 & 3.00 & 0.00 \\
\hline Squid meal & 1.00 & 1.00 & 1.00 & 1.00 & 1.00 \\
\hline Dried algae & 0.00 & 10.00 & 20.00 & 40.00 & 60.00 \\
\hline Wheat flour & 21.27 & 27.12 & 29.20 & 23.20 & 15.72 \\
\hline Vitamin $\operatorname{mix}^{1}$ & 1.43 & 1.43 & 1.43 & 1.43 & 1.43 \\
\hline Mineral mix $^{2}$ & 1.00 & 1.00 & 1.00 & 1.00 & 1.00 \\
\hline Methionine & 0.3 & 0.42 & 0.46 & 0.55 & 0.55 \\
\hline DL-Lysine & 1.00 & 1.00 & 1.10 & 1.30 & 1.30 \\
\hline Monocalcium phosphate & 1.50 & 1.50 & 1.50 & 1.50 & 1.50 \\
\hline Soybean oil & 2.00 & 0.15 & 0.07 & 0.02 & 0.00 \\
\hline Fish oil & 1.50 & 0.00 & 0.00 & 0.00 & 0.00 \\
\hline Binder & 0.00 & 0.00 & 0.00 & 0.00 & 0.50 \\
\hline Total & 100 & 100 & 100 & 100 & 100 \\
\hline \multicolumn{6}{|l|}{ Proximate Composition ( $\mathrm{gkg}^{-1}$ dry matter) } \\
\hline Crude Protein & 414.8 & 377.8 & 341.3 & 304.5 & 267.6 \\
\hline Crude fat & 71.0 & 78.5 & 94.7 & 156.7 & 207.4 \\
\hline $\mathrm{GE}(\mathrm{MJ} / \mathrm{kg})^{3}$ & 18.26 & 19.12 & 20.42 & 22.19 & 24.89 \\
\hline Protein/Energy $(\mathrm{P} / \mathrm{E})(\mathrm{mg}$ protein/KJ) & 22.72 & 19.75 & 16.71 & 13.72 & 10.75 \\
\hline
\end{tabular}

${ }^{1}$ One kilogram of vitamin mix contains: vitamin A $100000 \mathrm{IU}$, vitamin D $200000 \mathrm{IU}$, tocopherol acetate $3 \mathrm{~g}$, menadione $1 \mathrm{~g}$, thiamine $0.5 \mathrm{~g}$, riboflavin $1.5 \mathrm{~g}$, nicotinic acid $4 \mathrm{~g}$, Ca-pantothenate $2.5 \mathrm{~g}$, pyridoxine $0.8 \mathrm{~g}$, vitamin $\mathrm{B}_{12} 2 \mathrm{mg}$, folic acid $0.25 \mathrm{~g}$, biotin $8 \mathrm{mg}$, inositol $15 \mathrm{~g}$. ${ }^{2}$ One kilogram of mineral mix contains: $\mathrm{Ca}\left(\mathrm{H}_{2} \mathrm{PO}_{4}\right)_{2} 600 \mathrm{~g}, \mathrm{KCr}\left(\mathrm{SO}_{4}\right)_{2} 0.55 \mathrm{~g}, \mathrm{CuCO}_{3} 0.3 \mathrm{~g}, \mathrm{FeC}_{6} \mathrm{H}_{5} \mathrm{O}_{7} \cdot 10 \mathrm{~g}, \mathrm{MgO} 30 \mathrm{~g}, \mathrm{MnSO}_{4} 3.5 \mathrm{~g}, \mathrm{C}_{6} \mathrm{H}_{5} \mathrm{~K}_{3} \mathrm{O}_{7} \cdot \mathrm{H}_{2} \mathrm{O} 220 \mathrm{~g}, \mathrm{KI}_{0.02} \mathrm{~g}, \mathrm{~K}_{2} \mathrm{SO}_{4} 52 \mathrm{~g}, \mathrm{NaCl}_{74} \mathrm{~g}, \mathrm{Na}_{2} \mathrm{SeO}$ $0.02 \mathrm{~g}, \mathrm{ZnCO}_{3} 3 \mathrm{~g} .{ }^{3} \mathrm{ME}$ was a calculated value and others were measured values. $\mathrm{GE}(\mathrm{MJ} / \mathrm{kg}$ dry matter $)=23.4 \times \mathrm{CP}(\%)+39.2 \times \mathrm{EE}(\%)+17.2 \times \mathrm{CARB}(\%) . \mathrm{CARB}$ $(\%)=1-(\mathrm{CP}(\%)+\mathrm{EE}(\%)+$ Moisture $(\%))$. 


\subsection{Experimental Litopenaeus Vannamei}

A total of 20 cages placed in fixed positions in a $4000-\mathrm{m}^{2}$ pond were used in the trial. Postlarval shrimp were randomly assigned to the 20 cages. Each cage was equipped with an air pump to allow for continuous aeration. Before they were fed the treatment diets, all postlarval shrimp were fed the control diet for seven days to allow them to adapt to the testing environment. The duration of the trial was $50 \mathrm{~d}$. The water temperature, salinity, and dissolved oxygen levels were monitored daily using an YSI model 550A DO meter (YSI Inc., Yellow Springs, $\mathrm{OH}$, USA). Ammonia and $\mathrm{NO}_{2}$ levels were analyzed weekly and maintained within the ranges recommended for the commercial production of shrimp. The treatment diets were fed to the postlarval shrimp five times daily for the first 10 days and four times per day for the remainder of the trial period. The feeding rate (approximately $10-20 \%$ of the body weight) was adjusted based on satiation by observing the excess feed in the indicator net at the bottom of the cage and the food in the shrimp intestines. The feed intake was recorded daily for each cage. Dissolved oxygen (DO) levels of 6.5-7 $\mathrm{mg} \mathrm{L}^{-1}$,

\subsection{Measurements}

\subsubsection{Growth Performance}

The body weight of the postlarval shrimp in each cage was recorded at the beginning and end of the trial. Dead shrimp were also recorded and immediately removed from the cages. The feed conversion ratio (FCR) was calculated based on the body weight gain and consumed feed using the following formulas:

Initial body weight per shrimp $=$ (body weight of 100 shrimp at the beginning of the trial) / 100;

Final body weight per shrimp $=$ (body weight of total shrimp at the end of the trial) / final number of surviving shrimp per cage;

Body weight gain per shrimp = final body weight gain initial body weight;

Feed intake per shrimp $=$ sum of daily feed intake $/$ final number of surviving shrimp per cage;

$\mathrm{FCR}$ = feed intake per shrimp/body weight gain per shrimp;

Survival rate $=$ final number of shrimp per cage $/$ initial number of shrimp per cage $\times 100$;

Specific growth rate $(\mathrm{SGR}, \%)=\left(\log _{\mathrm{e}}\right.$ final weight $-\log _{\mathrm{e}}$ initial weight/Experimental days $) \times 100$.

\subsubsection{Sample Collection and Pretreatment}

At the end of the 50-day feeding trial, shrimp were collected from each cage for body weight and survival measurements. Fifty shrimp from each cage were randomly selected and used to obtain samples of serum, hepatopancreas, intestine and muscle. The shrimp were treated as follows: hemolymph was drawn from the pericardial cavity over an ice bath, pooled, and centrifuged (7000 g, $20 \mathrm{~min}, 4{ }^{\circ} \mathrm{C}$ ) to obtain the serum. The serum, hepatopancreas, and intestine samples were stored at $-20^{\circ} \mathrm{C}$ for future analysis, and the muscle samples were cut into pieces and freeze dried.

\subsubsection{Protein Content and Lipid Composition of Muscle}

Crude protein and crude fat analysis:

Crude protein $(\mathrm{CP}, \mathrm{N} \times 6.25)$ was determined using an automatic Kjel-Foss apparatus (2300; Foss Tecator AB, Höganäs, Sweden). Crude fat was determined by a modified Folch method [10]. After standing for $24 \mathrm{~h}, 10 \mathrm{ml}$ of the Folch extract (sample: Folch solution $=1: 20 \mathrm{~m}$ : v; Folch solution $=$ chloroform: methanol $2: 1 \quad \mathrm{v}$ : v) was filtered into a pre-weighed glass tube, and $2 \mathrm{ml}$ of $0.4 \% \mathrm{CaCl}_{2}$ was added. After allowing the sample to stand for $30 \mathrm{~min}, 2 \mathrm{ml}$ of eluent (chloroform: methanol: water 8:4:3, v: v: v) was pipetted in and out of the tube three times to rinse the tube wall. The solution was then evaporated to dryness in a vacuum drying oven (DZF-6050; Boxun Industry \& Commerce Co. Ltd., Shanghai, China). Finally, the sample tube was wiped to remove all traces of solvent and water and placed in a sealed vacuum tube. The fat content was determined gravimetrically, and the total lipids were taken up in $10 \mathrm{ml}$ of chloroform and then stored at $-20^{\circ} \mathrm{C}$ until analysis.

Fatty acid analysis:

Fatty acid methyl esters (FAMEs) were obtained by transesterification with $14 \% \quad \mathrm{BF} 3 /$ methanol using nonadecanoic acid ( $5 \%$ of total lipids) as the internal standard [11]. The FAMEs were separated by gas chromatography-mass spectrometry (models 7890A GC and 5975C GC/MS; Agilent, Santa Clara, CA, USA), using a non-polar capillary vessel column (Omegawax 320; Supelco, Bellefonte, PA, USA, $30 \mathrm{~m}$ long, $0.32 \mathrm{~mm}$ internal diameter, $0.25 \mu \mathrm{m}$ film thickness) with helium (purity $\geq 99.99 \%$ ) as the carrier gas. The column oven was held initially at $40^{\circ} \mathrm{C}$ for 2 $\mathrm{min}$; the temperature was then increased by $100^{\circ} \mathrm{C} / \mathrm{min}$ to $170^{\circ} \mathrm{C}$ and then by $20^{\circ} \mathrm{C} / \mathrm{min}$ to $240^{\circ} \mathrm{C}$, and then it was held for $3 \mathrm{~min}$. The total running time was $35.7 \mathrm{~min}$. The injection volume was $1 \mu \mathrm{l}$. The percentages of individual fatty acids were calculated according to the peak areas relative to that of the internal standard (nonadecanoic acid, 19:0) area. All fatty acid results are expressed as the mean $\pm \mathrm{SD} g / \mathrm{g}$ total fat.

\subsubsection{Digestive Enzyme Activities and Serum Biochemical Composition}

Prior to the enzyme activity analysis, the intestine or hepatopancreas samples from each group were homogenized in 1:4 normal saline $(\mathrm{m}: \mathrm{v})$ in an ice bath. The homogenate was centrifuged for $10 \mathrm{~min}$ at $12,000 \mathrm{rpm}$ at $4^{\circ} \mathrm{C}$. The supernatant was kept on ice prior to analysis. Protease activity was determined spectrophotometrically using a modification of the method of Folin-Ciocalteu [12]. Spectrophotometric measurements of lipase activity were performed using p-NPP as the substrate. The serum total protein (TP), triglyceride (TG), total cholesterol (TC), high-density lipoprotein-cholesterol (HDL-C), and low-density lipoprotein-cholesterol (LDL-C) were assayed using an autoanalyzer (model BS-300; Mindray, Shenzhen, China) [13]. 


\subsection{Statistical Analysis}

All statistical analyses were performed using SPSS 11.5 software. One-way analyses of variance (ANOVAs) were used to detect significant differences $(p<0.05)$ among treatment groups, and Duncan's multiple range test was applied to determine significant differences between treatment groups.

\section{Results}

\subsection{Effect of Dried Schizochytrium on the Growth Performance of Postlarval L. Vannamei}

The growth data (Table 2) showed that the final body weight, survival rate, FCR and SGR of the shrimp were significantly affected by supplementation of the diet with dried Schizochytrium. The best performance data were obtained with a diet containing $40 \%$ dried Schizochytrium. The survival rate of the $40 \%$ trial group was $24 \%$ higher than that of the shrimp fed the control diet $(p<0.05)$, although significant differences were not observed between the other three groups fed dried algae and the control group $(p>0.05)$. The final body weight gain and SGR peaked at $40 \%$ dried Schizochytrium $(p<0.05)$, and as the content of dried algae in the diet was further increased to $60 \%$, the final body weight gain and SGR decreased. The FCRs of the $20 \%$ and $40 \%$ trial groups were significantly lower than that of the control group $(p<0.05)$, although significant differences were not observed in the FCR among the control group, the $10 \%$ trial group and the $60 \%$ trial group.

Table 2. Effects of dried algaeSchizochytrium substitution on the production performance of post-larval L. vannamei. ${ }^{a}$

\begin{tabular}{|c|c|c|c|c|c|c|}
\hline $\begin{array}{l}\text { Dried algae } \\
\text { Schizochytrium } \\
\text { substitution level }\end{array}$ & $\begin{array}{l}\text { Initial body weight } \\
\text { (mg/shrimp) }\end{array}$ & $\begin{array}{l}\text { Final body weight } \\
\text { (g/shrimp) }\end{array}$ & $\begin{array}{l}\text { Final body weight } \\
\text { gain (g/shrimp) }\end{array}$ & $\begin{array}{l}\text { Specific } \\
\text { growth rate }\end{array}$ & $\begin{array}{l}\text { Feed conversion } \\
\text { ratio }\end{array}$ & $\begin{array}{l}\text { Survival rate } \\
(\%)\end{array}$ \\
\hline $0 \%$ & $16.2 \pm 0.32$ & $1.97 \pm 0.03^{\mathrm{c}}$ & $1.95 \pm 0.03^{\mathrm{c}}$ & $9.80 \pm 0.02^{\mathrm{c}}$ & $0.90 \pm 0.03^{\mathrm{a}}$ & $60.93 \pm 1.59^{\mathrm{b}}$ \\
\hline $10 \%$ & $16.5 \pm 0.29$ & $1.85 \pm 0.05^{\mathrm{c}}$ & $1.83 \pm 0.05^{\mathrm{c}}$ & $9.63 \pm 0.07^{d}$ & $0.84 \pm 0.02^{\mathrm{ab}}$ & $61.59 \pm 4.17^{\mathrm{b}}$ \\
\hline $20 \%$ & $16.4 \pm 0.26$ & $2.75 \pm 0.25^{b}$ & $2.73 \pm 0.25^{b}$ & $10.44 \pm 0.18^{\mathrm{b}}$ & $0.80 \pm 0.02^{\mathrm{bc}}$ & $64.42 \pm 1.97^{\mathrm{b}}$ \\
\hline $40 \%$ & $16.4 \pm 0.37$ & $3.52 \pm 0.16^{\mathrm{a}}$ & $3.50 \pm 0.16^{\mathrm{a}}$ & $10.96 \pm 0.10^{\mathrm{a}}$ & $0.77 \pm 0.03^{c}$ & $75.35 \pm 3.11^{\mathrm{a}}$ \\
\hline
\end{tabular}

${ }^{\text {a }}$ Different letters in the same column represent significant difference at $p<0.05$.

\subsection{Effect of Dried Schizochytrium on the Biochemical Composition of the Muscle tissue of Postlarval L. Vannamei}

The protein and ash contents of shrimp muscle were significantly affected by supplementation of the diet with different levels of dried Schizochytrium (Table 3). The muscle protein content of the shrimp fed diets containing $20 \%, 40 \%$ and $60 \%$ dried algae was higher than that of the shrimp fed the control diet $(p<0.05)$, although significant differences were not observed in the muscle protein content between the control group and the $10 \%$ trial group $(p>0.05)$. The ash contents of the $20 \%$ and $40 \%$ trial groups were significantly higher than that of the control group, although significant differences were not observed among the control group $(p<0.05)$, the $10 \%$ trial group and the $60 \%$ trial group $(p>0.05)$. The crude fat and moisture contents were similar in all groups $(p>0.05)$.

Table 3. Effect of dried algae Schizochytrium on Biochemical composition of post-larval L. vannamei muscle (\% air dry samples).

\begin{tabular}{|c|c|c|c|c|c|}
\hline \multirow{2}{*}{ Biochemical composition } & \multicolumn{5}{|l|}{ Diets } \\
\hline & $0 \%$ & $10 \%$ & $20 \%$ & $40 \%$ & $60 \%$ \\
\hline Moisture & $76.64 \pm 0.09$ & $76.46 \pm 0.21$ & $76.45 \pm 0.09$ & $76.33 \pm 0.10$ & $76.60 \pm 0.45$ \\
\hline Crude Protein & $87.69 \pm 0.26^{\mathrm{b}}$ & $88.30 \pm 0.17^{b}$ & $89.39 \pm 0.04^{\mathrm{a}}$ & $89.97 \pm 0.17^{\mathrm{a}}$ & $89.29 \pm 0.56^{\mathrm{a}}$ \\
\hline Crude fat & $5.56 \pm 0.08$ & $5.57 \pm 0.04$ & $5.58 \pm 0.03$ & $5.49 \pm 0.03$ & $5.52 \pm 0.04$ \\
\hline
\end{tabular}

${ }^{a b c}$ Values within the same line with different superscript letters represent significant difference $(P<0.05)$. a $>b>c$.

\subsection{Effect of Dried Schizochytrium on the Fatty Acid Composition of L. Vannamei Muscle Tissue}

Although dried algae were not present in the diet fed to the control group, the fish meal and fish oil provide DHA in the diet, resulting in the incorporation of DHA into the shrimp muscle tissue. Nevertheless, the replacement of feed with dried Schizochytrium led to further significant increases in the percentage of certain fatty acids in the muscle fat of the shrimp. The eicosapentaenoic acid (EPA) content of the $20 \%$ and $40 \%$ trial groups was significantly higher than that of the control group $(p<0.05)$. The DHA contents of the $10 \%, 20 \%$ and $40 \%$ trial groups were significantly higher than that of the control group $(p<0.05)$, although significant differences were not observed between the control group and the $60 \%$ trial group in DHA content $(p>0.05)$. The muscle PUFA content of all trial groups was significantly higher than that of the control group $(p<0.05)$, and the maximal muscle PUFA content was observed in the $40 \%$ trial group (Table 4 ). 

and Serum Biochemical Composition of Postlarval Litopenaeus vannamei

Table 4. Fatty acid composition (\% of total lipid) of L. vannameimuscle tissue (dry-basis matter).

\begin{tabular}{|c|c|c|c|c|c|}
\hline Fatty acids & $0 \%$ & $10 \%$ & $20 \%$ & $40 \%$ & $60 \%$ \\
\hline $14: 0^{*}$ & $0.16 \pm 0.01^{\mathrm{b}}$ & $0.23 \pm 0.01^{\mathrm{a}}$ & $0.21 \pm 0.02^{\mathrm{a}}$ & $0.17 \pm 0.01^{\mathrm{b}}$ & $0.18 \pm 0.01^{\mathrm{b}}$ \\
\hline 15:0 & $0.16 \pm 0.01^{\mathrm{bc}}$ & $0.18 \pm 0.01^{\mathrm{ab}}$ & $0.16 \pm 0.01^{\mathrm{bc}}$ & $0.15 \pm 0.01^{\mathrm{c}}$ & $0.18 \pm 0.01^{\mathrm{a}}$ \\
\hline $16: 0$ & $4.83 \pm 0.04^{c}$ & $5.56 \pm 0.05^{\mathrm{a}}$ & $5.19 \pm 0.05^{\mathrm{b}}$ & $4.71 \pm 0.06^{\mathrm{c}}$ & $5.59 \pm 0.03^{\mathrm{a}}$ \\
\hline $16: 1 n-7$ & $0.56 \pm 0.03^{\mathrm{bc}}$ & $0.61 \pm 0.02^{\mathrm{bc}}$ & $0.66 \pm 0.04^{b}$ & $0.61 \pm 0.01^{\mathrm{bc}}$ & $0.73 \pm 0.02^{\mathrm{a}}$ \\
\hline $17: 0$ & $0.51 \pm 0.02^{\mathrm{c}}$ & $0.46 \pm 0.01^{\mathrm{d}}$ & $0.46 \pm 0.01^{\mathrm{d}}$ & $0.55 \pm 0.01^{\mathrm{b}}$ & $0.62 \pm 0.01^{\mathrm{a}}$ \\
\hline 18:0 & $2.51 \pm 0.02^{\mathrm{d}}$ & $2.67 \pm 0.02^{\mathrm{bc}}$ & $2.75 \pm 0.03^{\mathrm{ab}}$ & $2.59 \pm 0.07^{\mathrm{cd}}$ & $2.81 \pm 0.03^{\mathrm{a}}$ \\
\hline 18:1n-9 & $3.26 \pm 0.06^{\mathrm{c}}$ & $3.57 \pm 0.03^{\mathrm{a}}$ & $3.40 \pm 0.02^{\mathrm{b}}$ & $3.28 \pm 0.06^{\mathrm{c}}$ & $3.44 \pm 0.03^{\mathrm{b}}$ \\
\hline $18: 2 n-6$ & $2.29 \pm 0.02^{\mathrm{a}}$ & $2.34 \pm 0.04^{\mathrm{a}}$ & $2.13 \pm 0.02^{\mathrm{c}}$ & $2.14 \pm 0.12^{\mathrm{bc}}$ & $2.19 \pm 0.01^{\mathrm{b}}$ \\
\hline $18: 3 n-3$ & $0.41 \pm 0.01^{\mathrm{c}}$ & $0.44 \pm 0.02^{\mathrm{c}}$ & $0.60 \pm 0.02^{\mathrm{a}}$ & $0.51 \pm 0.02^{\mathrm{b}}$ & $0.58 \pm 0.02^{\mathrm{a}}$ \\
\hline 20:0 & $0.07 \pm 0.10^{\mathrm{a}}$ & $0.06 \pm 0.01^{\mathrm{a}}$ & $0.05 \pm 0.01^{\mathrm{b}}$ & $0.06 \pm 0.01^{\mathrm{a}}$ & $\mathrm{NA}^{* *}$ \\
\hline $20: 4 n-6$ & $1.03 \pm 0.03^{b}$ & $1.04 \pm 0.01^{\mathrm{b}}$ & $1.05 \pm 0.02^{\mathrm{b}}$ & $1.06 \pm 0.02^{\mathrm{b}}$ & $1.26 \pm 0.03^{\mathrm{a}}$ \\
\hline 20:5n-3 (EPA) & $5.17 \pm 0.04^{\mathrm{c}}$ & $5.29 \pm 0.09^{\mathrm{bc}}$ & $5.40 \pm 0.07^{\mathrm{ab}}$ & $5.46 \pm 0.04^{\mathrm{a}}$ & $5.24 \pm 0.03^{c}$ \\
\hline $22: 6 n-3$ (DHA) & $5.56 \pm 0.03^{\mathrm{d}}$ & $5.89 \pm 0.09^{\mathrm{bc}}$ & $6.01 \pm 0.10^{\mathrm{b}}$ & $6.34 \pm 0.10^{\mathrm{a}}$ & $5.74 \pm 0.03^{\mathrm{cd}}$ \\
\hline $\mathrm{SFA}^{1}$ & $8.25 \pm 0.07^{\mathfrak{c}}$ & $9.17 \pm 0.05^{\mathrm{a}}$ & $8.83 \pm 0.10^{\mathrm{b}}$ & $8.24 \pm 0.14^{\mathrm{c}}$ & $9.39 \pm 0.03^{\mathrm{a}}$ \\
\hline MUFA $^{2}$ & $3.82 \pm 0.06^{\mathrm{b}}$ & $4.18 \pm 0.05^{\mathrm{a}}$ & $4.06 \pm 0.02^{\mathrm{a}}$ & $3.89 \pm 0.06^{\mathrm{b}}$ & $4.17 \pm 0.02^{\mathrm{a}}$ \\
\hline PUFA $^{3}$ & $14.46 \pm 0.09^{\mathrm{c}}$ & $15.01 \pm 0.21^{\mathrm{b}}$ & $15.19 \pm 0.17^{\mathrm{ab}}$ & $15.51 \pm 0.18^{\mathrm{a}}$ & $15.01 \pm 0.10^{\mathrm{b}}$ \\
\hline DHA+EPA & $10.73 \pm 0.03^{\mathrm{d}}$ & $11.19 \pm 0.16^{\mathrm{bc}}$ & $11.41 \pm 0.12^{\mathrm{b}}$ & $11.80 \pm 0.14^{\mathrm{a}}$ & $10.98 \pm 0.06^{\mathrm{c}}$ \\
\hline
\end{tabular}

${ }^{\text {abc }}$ Values within the same line with different superscript letters represent significant difference $(\mathrm{P}<0.05)$.

*Significantly different $(P<0.05) ; * *$ NA: Not detected.; ${ }^{1}$ Saturated fatty acids: C14:0, C15:0, C16:0, C17:0, C18:0, C20:0; ${ }^{2}$ Monounsaturated fatty acids: C16:1 n-7, C18:1 n-9; ${ }^{3}$ Polyunsaturated fatty acids: C18:2 n-6, C18:3 n-3, C20:4 n-6, C20:5 n-3, C22:6 n-3.

\subsection{Effect of Dried Schizochytrium on Digestive Enzyme Activities in the Intestine and Hepatopancreas of $L$. Vannamei}

The level of dried Schizochytrium in the diet had significant effects on the specific activities of proteases and lipases in the hepatopancreas and intestine (Table 5) and decreased the protease specific activity but increased the lipase activity. In the hepatopancreas, the protease activity of the control group was significantly higher than that of the trial groups $(p<0.05)$, although the lipase activity of the control group was significantly lower than that of the trial groups $(p<0.05)$. In the intestine, the protease activity of the control group was significantly higher than that of the $60 \%$ trial group $(p<0.05)$, whereas significant differences in protease activity were not observed between the control group and the other trial groups. The lipase activity of the control group was significantly lower than that of the $20 \%, 40 \%$ and $60 \%$ trial groups $(p<$ $0.05)$.

Table 5. Specific activities of protease and lipase in L. vannamei hepatopancreas and intestine.

\begin{tabular}{|c|c|c|c|c|c|}
\hline & \multicolumn{5}{|l|}{ Diets } \\
\hline & $0 \%$ & $10 \%$ & $20 \%$ & $40 \%$ & $60 \%$ \\
\hline Hepatopancreas (u/mgprot) Protease & $196.38 \pm 6.74^{\mathrm{a}}$ & $125.63 \pm 7.55^{\mathrm{c}}$ & $154.70 \pm 12.70^{\mathrm{b}}$ & $163.76 \pm 7.83^{b}$ & $148.26 \pm 8.76^{b}$ \\
\hline Lipase & $12.48 \pm 0.92^{\mathrm{c}}$ & $15.62 \pm 0.88^{b}$ & $17.74 \pm 1.24^{\mathrm{ab}}$ & $19.22 \pm 0.87^{\mathrm{a}}$ & $18.45 \pm 0.82^{\mathrm{a}}$ \\
\hline \multicolumn{6}{|l|}{ Intestine (u/mgprot) } \\
\hline Protease & $265.23 \pm 8.75^{\mathrm{a}}$ & $242.16 \pm 9.55^{\mathrm{ab}}$ & $236.57 \pm 17.85^{\mathrm{ab}}$ & $246.61 \pm 12.54^{\mathrm{ab}}$ & $223.07 \pm 11.16^{\mathrm{b}}$ \\
\hline Lipase & $8.97 \pm 0.39^{c}$ & $11.62 \pm 1.03^{\mathrm{bc}}$ & $15.07 \pm 1.31^{\mathrm{a}}$ & $16.31 \pm 0.88^{\mathrm{a}}$ & $12.20 \pm 1.21^{\mathrm{b}}$ \\
\hline
\end{tabular}

${ }^{a b c}$ Values within the same line without same superscript letters represent significant difference $(\mathrm{P}<0.05)$. $a>b>c$.

\subsection{Effect of Dried Schizochytrium on the Biochemical Composition of the Serum in L. Vannamei}

The serum biochemical composition of the shrimp was significantly affected by the level of dried Schizochytrium in the diet $(p<0.05)$ (Table 6). The TP of the control group was significantly higher than that of the $60 \%$ trial group, although significant differences were not observed in the TP between the control group and the other trial groups $(p>0.05)$. Similar TG levels were observed in the $10 \%$ and $60 \%$ trial groups $(p>$ $0.05)$ compared with those in the control group, although higher TG levels were observed in the $20 \%$ and $40 \%$ trial groups $(p<0.05)$. The inclusion of dried Schizochytrium in the diet decreased the serum TC of the shrimp. The TC of the $40 \%$ and $60 \%$ trial groups was significantly lower than that of the control group $(p<0.05)$. As the dried algae content of the diet increased from $0 \%$ to $40 \%$, the serum HDL-C/LDL-C ratio increased significantly from 0.37 to $1.31(p<0.05)$, which represented an increase of $129.82 \%$ from the HDL-C/LDL-C ratio of the control group. 
Table 6. Analysis ofTP, TG, TC, and HDL-C/LDL-C composition of serum.

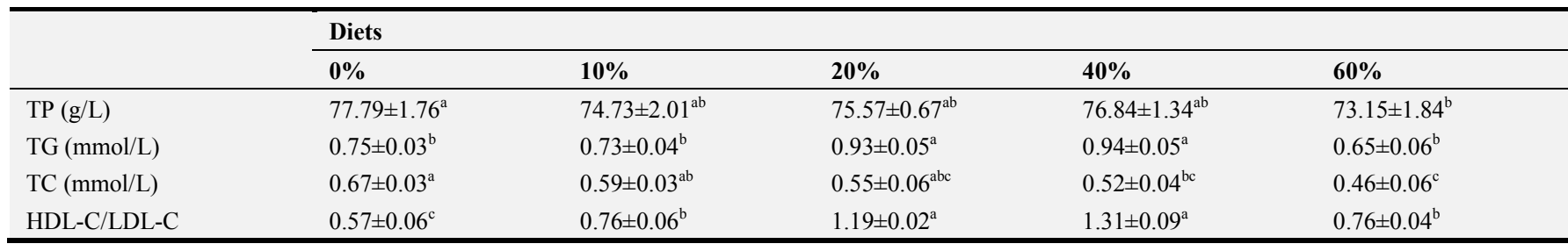

${ }^{a b c}$ Values within the same line with different superscript letters represent significant difference $(P<0.05)$. $a>b>c$.

TC: total cholesterol, TP: total protein, TG: triglyceride, HDL-C: high-density lipoprotein cholesterol, LDL-C: low-density lipoprotein cholesterol.

\section{Discussion}

\subsection{Effect of Dietary Dried Schizochytrium Levels on Growth Performance of L. Vannamei}

Although L. vannamei is an important aquaculture species, few studies have focused on its lipid requirements [14-16]. Previous studies [17] reported that the growth rate of juvenile shrimp was improved by the addition of DHA to the diet. Although the underlying mechanism is not clear, this effect may be partially related to the increased dietary DHA/EPA ratio. As the dietary $\mathrm{DHA} / \mathrm{EPA}$ increased from 0.61 to 2.17 , the SGR increased significantly from $2.03 \%$ day $^{-1}$ to $2.26 \%$ day $^{-1}$ in the large yellow croaker Larimichthys crocea [18]. The main sources of DHA in commercial feed are fish meal and fish oil. However, the yields of fish meal and fish oils are dwindling, and the future supply will be insufficient to meet the increasing demands of aquaculture feeds, especially in prawn farming. Therefore, the sources of essential fatty acids for shrimp are becoming limited [19]. Consequently, research into alternative protein sources for feeds is rapidly increasing [20], and achieving an appropriate balance of fatty acids in substituted shrimp feed is an important area of current research. In this study, we increased the DHA content of shrimp feed by replacing other feed components with various levels of the alga Schizochytrium and found that the body weight gain, SGR, and survival rate of postlarval shrimp fed diets containing $20-40 \%$ dried Schizochytrium were significantly higher than those of the shrimp fed a control diet. Our results suggest that addition of dried Schizochytrium to shrimp diet can significantly improve the growth performance of postlarval shrimp. Adding dried Schizochytrium to feed could represent an optimal method of increasing the DHA content of the feed, which is required for the growth of shrimp. Moreover, as the amount of dried Schizochytrium in the diet increased from $40 \%$ to $60 \%$, the body weight gain, SGR and survival rate decreased to levels similar to those observed in the $20 \%$ group. The adverse effect of $60 \%$ dried algae substitution might have been related to the lower protein level in the diet (Table 1). The unbalanced ratio of protein to energy might lead to decreased growth performance in the shrimp fed a diet containing $60 \%$ dried algae. When the dietary content of dried algae increased from $20 \%$ to $40 \%$, the $\mathrm{P} / \mathrm{E}$ ratio remained in the range of 13.72 to $16.71 \mathrm{mg}$ protein $/ \mathrm{KJ}$; thus, dietary supplementation with Schizochytrium allows for a decrease in the fish meal and protein content of the diet without adverse effects on the growth performance of $L$. vannamei (Table 1). Thus, $20-40 \%$ Schizochytrium in the diet is a suitable dosage under the experimental conditions employed in this study.

\subsection{Effect of the Dried Schizochytrium Level on the Biochemical and Fatty Acid Composition of the Muscle Tissue in L. Vannamei}

A number of studies of alternatives to fish oil and fish meal, including plant oils and plant proteins, reported a lack of significant differences when supplements with high and low levels of DHA were used, which may be related to the rearing environment [21]. Our study achieved similar results and showed that the use of various levels of dried Schizochytrium in the diet did not affect the crude fat content of the shrimp muscle. However, the protein and ash content increased significantly, suggesting that supplementation with dried Schizochytrium accelerated the deposition of protein, minerals and trace elements.

HUFAs are essential fatty acids for crustacean species. The fatty acid composition of feed is not only important for the growth of shrimp but may also influence the composition of fatty acids in shrimp muscle. Because shrimp represents a food source of HUFAs for humans, especially DHA and EPA, it would be better to retain high levels of $n-3$ HUFA in farmed shrimp. Researchers have reported that the DHA content of shrimp tail muscle tissue was proportional to the dietary DHA level [22, 23]. González-Félix et al. [22] evaluated the effects of feeding various phospholipid levels and oil types on the fatty acid composition of $L$. vannamei muscle and found that the arachidonic acid (ARA), EPA, and DHA contents of the muscle were highly positively correlated with the HUFA content of the feed $(p<0.05)$. Forster et al. [24] replaced fish meal with various levels of soybean meal and compared the effects of feeding fish oil and linoleic acid-enhanced soybean oil on the deposition of fatty acids in the muscle of Pacific white shrimp (L. vannamei), and they found that in the low-fish-meal groups ( $19 \%$ and $0 \%$ ), the $n-3$ HUFA content of the whole body and muscle decreased significantly when fish oil was replaced with enhanced soybean oil $(p<0.05)$, whereas an obvious change in the total fat content of the muscle was not observed $(p>0.05)$. Consistent with the results of previous studies [22, 24], we found that as the dried Schizochytrium dosage increased, the crude fat content of the muscle did not undergo any major changes; however, the HUFA content of the muscle gradually increased and peaked 
in the $40 \%$ group, indicating that the relative accumulation of HUFAs in muscle fatty acids is not correlated with the total fat deposition but is related to the HUFA content of the feed. Therefore, as an alternative source of n-3 HUFAs, dried Schizochytrium can be used to increase the accumulation of HUFAs, especially DHA, in shrimp.

\subsection{Effect of the Dried Schizochytrium Level on Digestive Enzyme Activities and Biochemical Composition of Serum in L. Vannamei}

The intestine and hepatopancreas are the main sites of digestion and absorption of nutrients [25]. Increasing the dried Schizochytrium content of the diet was accompanied by increased lipase activity in the intestine; as a result, the fats in the feed were completely digested. However, the protease activity showed opposite results, which may partially explain the lower energy protein decomposition and the increase of protein content in the muscle.

Fat can be divided into cholesterols, triglycerides, phospholipids, and free fatty acids. Hemolymph is central to fat absorption and transportation. Triglycerides and free fatty acids are energy sources that are transported by hemolymph between adipose tissue and the liver. Long-chain fatty acids are mainly transported in the hemolymph in the form of triglycerides. DHA promotes fat catabolism and facilitates the transport of triglycerides from the liver to the tissues, wherein they are metabolized to produce energy. González [22] found that in juvenile L. vannamei fed equal amounts of phospholipids, increasing the dosage of DHA can elevate the serum triglyceride content. Similarly, we observed that the total serum triglyceride level increased significantly as the dietary content of dried Schizochytrium increased $(p<0.05)$, indicating an increase in the amount of long-chain fatty acids in the serum. As an important functional substance in the body, cholesterol is an essential lipid for the growth and development of shrimp, and it is mainly transported by lipoproteins in the hemolymph. High-density lipoprotein (HDL) and low-density lipoprotein (LDL) have opposite physiological functions in cholesterol transport, with HDL transporting hemolymph cholesterol into the liver and LDL performing the reverse action. An elevation or reduction in the HDL/LDL ratio indicates whether blood cholesterol is entering the liver to participate in metabolic activity or being transported from the liver to be deposited in tissues [26, 27]. In the present study, the total cholesterol level decreased slightly but not significantly as the dietary content of dried algae increased, whereas the HDL/LDL ratio initially increased and then decreased. These results suggest that including an appropriate amount of dried Schizochytrium in the diet can promote blood cholesterol transport to the liver and thereby prevent the accumulation of cholesterol in the blood vessels, improve the efficiency of cholesterol utilization, and maintain homeostasis of cholesterol within the hemolymph.

\section{Conclusions}

The addition of dried Schizochytrium to shrimp feed not only improved the growth performance of postlarval shrimp but also enhanced the accumulation of HUFAs in shrimp muscle. Dried Schizochytrium can be considered a highly nutritive product for use in fortifying commercial compound larval feed for the hatchery and nursery phases of shrimp production. The suggested replacement percentage of commercial compound larvae feed by dried Schizochytrium ranges from 20 to $40 \%$. The best replacement percentage of dried Schizochytrium would be $40 \%$. The use of such a supplement can increase the amount of HUFAs and reduce the level of protein required for the production of high-quality feed.

\section{Acknowledgements}

The authors wish to acknowledge Roquette Management (Shanghai) Co., Ltd., China, for providing funds for this study.

\section{References}

[1] Bengtson DA, Léger P, Sorgeloos P (1991) Use of Artemia as a food source for aquaculture. In Artemia Biology. Edited by Browne RA, Sorgeloos P, Trotman CNA. Boca Raton, FL: CRC Press; 1991, 255-285.

[2] Tacon, A. G. J. \& Akiyama, D. M. (1997). Feed ingredients. In Crustacean Nutrition Advances in World Aquaculture (D_Abramo, L. R., Conklin, D. E. \& Akiyama, D. M. eds), pp. 41- -472 . World Aquaculture Society, Baton Rouge, LA, USA.

[3] Motte Constant, Rios Alfredo, Lefebvre Thomas, Do Hong, Henry Morgane, Jintasataporn Orapint. (2019). Replacing Fish Meal with Defatted Insect Meal (Yellow Mealworm Tenebrio molitor) Improves the Growth and Immunity of Pacific White Shrimp (Litopenaeus vannamei) [J]. Animals: an open access journal from MDPI, 9 (5).

[4] Shan H, Zhao X, Zhou Y, et al. (2019). Effects of freeze-dried powder of the Antarctic krill Euphausia superba on the growth performance, molting and fatty acid composition of the Pacific white shrimp Litopenaeus vannamei $[\mathrm{J}]$. Aquaculture Research, 00: $1-12$.

[5] Vikas Kumar, Habte-Michael Habte-Tsion, El-Haroun E. et al. (2018). Replacement of fish oil with Schizochytrium meal and its impacts on the growth and lipid metabolism of Pacific white shrimp (Litopenaeus vannamei) [J]. Aquaculture Nutrition, $1-13$.

[6] César Molina-Poveda, Ricardo Cárdenas, Jover M. (2015). Evaluation of amaranth (Amaranthus caudatus L.) and quinoa (Chenopodium quinoa) protein sources as partial substitutes for fish meal in Litopenaeus vannamei grow-out diets [J]. Aquaculture Research, 2015: n/a-n/a.

[7] Samocha, T. M., Patnaik, S., Davis, D. A., Bullis, R. A. \& Browdy, C. L. (2010). Use of commercial fermentation products as HUFA source in practical diets for the Pacific white shrimp Litopenaeus vannamei. Aquacult. Res., 41, 961-967.

[8] Patnaik, S., Samocha, T. M., Davis, D. A., Bullis, R. A. \& Browdy, C. L. (2006). The use of algal meals as highly unsaturated fatty acid sources in practical diets designed for Litopenaeus vannamei. Aquacult. Nutr., 12, 395-401. 
[9] Hamidoghli A, Yun H, Shahkar E, et al. (2018). Optimum dietary protein-to-energy ratio for juvenile whiteleg shrimp, Litopenaeus vanname, reared in a biofloc system [J]. Aquaculture Research, 1-12.

[10] Iverson S J, Lang S L, Cooper M H (2001). Comparison of the Bligh and Dyer and Folch methods for total lipid determination in a broad range of marine tissue. Lipids 36 (11), 1283-1287.

[11] Morrison W R, Smith L M (1964). Preparation of fatty acid methyl esters and dimethylacetals from lipids with boron fluoride-methanol. J Lipid Res 5 (4), 600-608.

[12] Ledoux M, Lamy F (1986). Determination of proteins and sulfobetaine with the folin-phenol reagent. Anal Biochem 157 (1), 28-31.

[13] Gupta N, Rathi P, Gupta R (2002). Simplified para-nitrophenylpalmitate assay for lipases and esterases. Anal Biochem 311 (1), 98-99.

[14] Ju Z Y, Castille F, Deng D, Dominy W G, Lawrence A L, Forster I P (2012). Effects of replacing fish oil with stearine as main lipid source in diet on growth and survival of Pacific White Shrimp, Litopenaeus vannamei (Boone, 1931). Aquac Res 43 (10), 1528-1535.

[15] Niu J, Liu Y J, Tian L X, Mau K S, Lin H Z, Chen X, Yang H J, Liang G Y (2011). Influence of dietary phospholipids level on growth performance, body composition and lipid class of early post larval Litopenaeus vannamei. AquacultNutr 17 (2), E615-E621.

[16] Zhang S P, Li J F, Xiao Chun W, Zhong W J, Xian J A, Liao S A, Miao Y T, Wang A L (2013) Effects of different dietary lipid level on the growth, survival and immune-relating genes expression in Pacific white shrimp, Litopenaeus vannamei. Fish Shellfish Immun 34 (5), 1131-1138.

[17] González-Félix M L, Gatlin III D M, Lawrence A L, et al. (2002). Effect of dietary phospholipid on essential fatty acid requirements and tissue lipid composition of Litopenaeus vannamei juveniles. Aquaculture, 207 (1), 151-167.

[18] Zuo Rantao, Ai Qinghui, Mai Kangsen, et al., (2012). Effects of dietary docosahexaenoic to eicosapentaenoic acid ratio (DHA/EPA) on growth, nonspecific immunity, expression of some immune related genes and disease resistance of large yellow croaker (Larmichthyscrocea) following natural infestation of parasites (Cryptocaryonirritans). Aquaculture 334-337, 101-109.
[19] Sookying D, Davis D A (2011). Pond production of Pacific white shrimp (Litopenaeus vannamei) fed high levels of soybean meal in various combinations. Aquaculture 319 (1), 141-149.

[20] Zhong G, Hua X, Yuan K, Zhou H (2011. Effect of CGM on growth performance and digestibility in puffer (Takifugufasciatus). AquacultInt 19 (3), 395-403.

[21] Izquierdo M, Forster I, Divakaran S, Conquest L, Decamp O, Tacon A (2006). Effect of green and clear water and lipid source on survival, growth and biochemical composition of Pacific white shrimp (Litopenaeus vannamei). Aquacult Nutr 12 (3), 192-202.

[22] González-Félix M L, Da Silva F S D, Davis D A, Samocha T M, Morris T C, Wilkenfeld J S, Perez-Velazquez M (2010). Replacement of fish oil in plant based diets for Pacific white shrimp (Litopenaeus vannamei). Aquaculture 309 (1), 152-158.

[23] Mercier L, Racotta I S, Yepiz-Plascencia G, Muhlia-Almazán A, Civera R, Quiñones-Arreola M F, Wille M, Sorgeloos P, Palacios E (2009). Effect of diets containing different levels of highly unsaturated fatty acids on physiological and immune responses in Pacific whitelegshrimp Litopenaeus vannamei (Boone) exposed to handling stress. Aquac Res 40 (16), 1849-1863.

[24] Forster I P, Dominy W G, Obaldo L G, et al. (2011). The effect of soybean oil containing stearidonic acid on growth performance, n-3 fatty acid deposition and sensory characteristics of pacific white shrimp (Litopenaeus vannamei) Aquaculture nutrition, 17 (2), 200-213.

[25] Wang Y (2007) Effect of probiotics on growth performance and digestive enzyme activity of the shrimp, Penaeusvannamei. Aquaculture 269 (1), 259-264.

[26] Xiang Dong L, RuiTao X, LingXiang Z, et al. (2011). Effects of different lipids in dietary feed of Litopenaues vannamei juvenile prawn on its growth and composition of liver fatty acids. Journal of Southern Agriculture, 42 (4), 441-445.

[27] Li X H, Wang B J, Wang L, et al. (2008). Biochemical characterization and molecular cloning of penaeid shrimp hemolymph lipoproteins. Marine Science, 32 (11): 80-83. 